\title{
Kuinka riidellä taloustieteilijöiden kanssa?
}

\section{Veikko Eranti, VTT, tutkijatohtori, poliittisen sosiologian tutkija,Tampereen yliopisto}

Dani Rodrik: Economics rules. Rights and wrongs of the dismal science. W.W. Norton \& Company 2015.

Taloustieteillä on keskeinen asema yhteiskunnallisessa keskustelussa. Media, poliitikot ja virastot käyttävät taloustieteilijöitä asiantuntijoina, ja ministeriöt perustavat tekemisensä taloustieteellisiin ennustuksiin. Taloustieteilijöiden kanssa keskusteleminen on yllättävän vaikeaa suhteessa näin korostuneeseen asemaan. On selvää, ettei kukaan erityisesti pidä itseään tai tieteenalaansa kohtaan esitetystä kritiikistä. Taloustietelijöiden kohdalla kyse tuntuu kuitenkin olevan jostakin syvemmästä: heitä kohtaan esitetty kritiikki koetaan paitsi väärään maaliin osuvana myös jotenkin kategorisesti vääränä tai jopa loukkaavana - ikään kuin itse keskustelun käyminen sinänsä olisi koko ajan väärin.

Miten taloustietelijöiden kanssa sitten pitäisi keskustella, mikäli tavoitteena olisi ajattelun edes jonkinlainen edistyminen? Tähän kysymykseen antaa vastauksia Dani Rodrikin Economics rules. Rodrik on Harvardissa työskentelevä taloustieteen professori, joka on muun muassa yksi kehitystaloustieteen vaikutusvaltaisimmista ajattelijoista. Rodrik pyrkii kuvaamaan tieteenalansa onnistumiset ja epäonnistumiset, esittämään yleisen mallin taloustieteiden toiminnasta sekä ne kohdat, joissa tieteellä ihmisten tekemänä ja siten lähtökohtaisen sotkuisena toimintana olisi parannettavaa.

Economics rules on kirja, jolla on missio. Se (vaatimattomasti) pyrkii pelastamaan taloustieteen - sekä itseltään että liian ignoranteilta kriitikoiltaan. Kirja on yleistajuinen esitys siitä, mitä taloustiede on, normatiivinen puheenvuoro siitä, mitä taloustieteen pitäisi olla, peruskurssi siihen, miten taloustietelijöiden kanssa pitäisi keskustella ja ohjekirja taloustieteilijöille siihen, miten 
ei-ekonomistien kanssa pitäisi keskustella. Rodrikin ydinpositio on yksinkertaisesti ilmaistuna se, että valtavirtainen taloustiede on kokoelma hyvinkin erilaisia malleja, joista kuhunkin tilanteeseen pitää valita se, joka tilannetta parhaiten kuvaa.

Kirjalla on kaksi keskeistä väitettä. Näistä ensimmäinen koskee abstrahointia eli mallien käyttöä taloustieteessä. Tämä - väitteiden yksinkertaistaminen mahdollisimman testattavaan ja laskettavaan muotoon - tarjoaa taloustieteelle sellaista täsmällisyyttä ja yleistettävyyttä, mikä muilta yhteiskuntatieteiltä helposti puuttuu. Toinen keskeinen väite liittyy ajatukseen taloustieteestä mallien kokoelmana, ei minään yhtenäisenä yhden oikean mallin tieteenä. Rodrik väittää nimenomaan mallien välillä valitsemisen taidon jääneen taloustieteen tutkimuksessa, opetuksessa ja keskustelussa liian vähälle huomiolle. Näillä väitteillä Rodrik tulee sanoneeksi, kuten myös eräät suomalaiset taloustieteilijät ovat väittäneet, että ei ole olemassa erikseen heterodoksista ja ortodoksista taloustiedettä - mutta samaan aikaan, että 1) taloustieteilijöiden pitää osata operoida myös muilla kuin vapaiden tehokkaiden täydellisen informaation markkinoiden malleilla ja 2) ainoastaan malleja käyttävät tutkijat ovat oikeastaan taloustieteilijöitä. Mallit kuitenkin tarvitsevat tuekseen empiriaa. Rodrikille todellinen maailma on aina se lopullinen mittatikku, jota vasten malleja punnitaan.

Kirjan arvioinnin keskeiseksi kysymykseksi nouseekin, kohtalaisen ironisesti, missä määrin Rodrikin muodostama teoreettinen malli taloustietelijöistä vastaa empiirisesti havaittavien taloustietelijöiden käyttäytymistä.

\section{Taloustieteilijöiden sadut}

Rodrikille taloustieteiden tapa käyttää matematiikkaa ja muodostaa malleja vertautuu ajatuskokeisiin ja faabeleihin. Taloustieteiden keskeinen perustelu oman tieteenalansa muita yhteiskuntatieteitä suuremmalle tieteellisyydelle perustuu siis satuihin.

Näiden mallien (tai satujen) tarkoituksena on eristää maailmasta juuri se vaikutus, josta ollaan kiinnostuneita. Mallien hyöty piilee pelkistämisessä: tavoitteena on rakentaa malli, joka on niin yksinkertainen kuin mahdollista, muttei yhtään yksinkertaisempi. Matematiikan (yksi) rooli on formalisoida 
päättely ja tämän formalisoinnin kautta erotella mallien kriittiset oletukset vähemmän kriittisistä.

Taloustieteilijän modus operandi on rakentaa mahdollisimman yleisesti päteviä ja mahdollisimman yksinkertaisia malleja maailmasta, todellisuuden reduktioiden kautta. Suuri osa näistä reduktioista on paikkaansa pitämättömiä ja parhaimmillaankin summittaisia. Tämä ei Rodrikille suinkaan ole ongelma, vaan päinvastoin tieteenalan keskeinen vahvuus, pyrkimys abstraktin tason teorianmuodostukseen. Olennaista on erottaa, mitkä näistä reduktioista ovat kriittisiä ja mitkä eivät. Taloustieteilijät eivät siis vakuutu kritiikistä, jonka mukaan jokin malli on liian yksinkertaistava ja redusoi maailman liian simppeliksi, sillä tämä on mallien eksplisiittinen tehtävä. Tämä menee välillä toki saivarteluksi: politiikkatoimista keskusteltaessa arkikielessä ero sen välillä, kritisoiko mallia yleisesti todellisuuden liian kapeasta ymmärtämisestä vaiko jonkin tietyn kriittisen interaktion tai oletuksen unohtamisesta ei aina ole niin suuri kuin miltä se piirustuspöydän ääressä vaikuttaa.

Mallien käyttö siis mahdollistaa kumuloitumisen ja täsmällisen keskustelun, mutta on äärimmäisellä yksinkertaistamisella hallapuolensakin. Vaikkapa etnografia metodina tavoittaa aidosti ilmiöitä, joista taloustieteilijä voi unelmoida, mutta toisaalta parhaatkin yritykset tiedon kumuloitumiseksi tuppaavat valumaan tyhjiin. Muilla yhteiskuntatieteillä onkin suhteessa taloustieteisiin sekä opittavaa että syytä polleuteen.

Vaikka koko Rodrikin kirja on taloustieteiden puolustuspuhe, on se myös tieteenalan sisäistä polemisointia. Liialliseen matemaattiseen sofistikoitumiseen takertuminen, liiallinen yhtälönnysvääminen ja malliaskartelu eivät Rodrikia vakuuta. Hänelle matematiikan käyttö ei oikeastaan ole edes välttämätöntä faabelien rakennuksessa.

\section{Tuomari vai lääkäri?}

Painavin kritiikki jonka Economics rules esittää institutionalisoitunutta taloustiedettä kohtaan liittyy sen valintaan, mikä satu mihinkin tilanteeseen parhaiten sopii. Rodrikille taloustiede on aina kokoelma erilaisia, toisiaan täydentäviä ja välillä keskenään ristiriidassa olevia malleja. Mikäli tällaisen tieteen pohjalta pyritään vaikkapa antamaan politiikkasuosituksia, on tärkeää, että tilanteeseen 
on valittu sopiva malli. Tätä mallin valintaa ei kuitenkaan juuri opeteta, siitä ei puhuta, eikä sitä tutkita. Liian usein taloustieteilijät esiintyvät julkisuudessa kuin olisi oikeasti olemassa vain yksi jokaiseen tilaisuuteen sopiva malli. Tämä saattaa liittyä siihen, että mallinvalinta on enemmän tutkijan käsityötaitoa kuin varsinaista tieteellistä toimintaa.

Rodrikin ainakin politiikan tasolla vaikutusvaltaisimmat aiemmat työt liittyvät keskeisesti keskusteluun mallin valinnasta. Rodrik formalisoi Ricardo Hausmanin kanssa growth diagnostics -ajattelua, joka haastoi kehitystaloustieteessä niin sanotun Washingtonin konsensuksen. Jos Washingtonin konsensus oli yksimielisyys siitä, millaisilla resepteillä kehittyvät taloudet pääsevät kasvuun (deregulaatio, ulkomaankaupan vapauttaminen, yksityistäminen - mutta myös esimerkiksi koulutukseen panostaminen), on growth diagnostics -ajattelun ytimessä kunkin spesifin kehittyvän talouden ymmärtäminen. Hausmanin ja Rodrikin ajattelussa painotetaan taloustieteellisten mallien moninaisuutta: taloustieteilijä on oireita diagnosoiva lääkäri, joka selvittää, mikä on kuinkin kansantalouden kasvun este, ja suosittelee politikkatoimia juuri tämän esteen korjaamiseksi - ei tuomari, jolla on hallussaan yleinen totuus. Ja kun hoito on annettu, lääkäri seuraa potilaan kuntoa. Rodrikin taloustieteessä empiria aina lopulta ratkaisee.

Sosiologin on hieman vaikea pitää vakavaa naamaa. Toisille sosiaalitieteen lajeille tämä tilanteiden moninaisuus ja kuhunkin tilanteeseen sopivan lähtökohdan valitseminen on lähtökohta, ei uudistus.

Rodrikin koko kirjan kannalta olennainen kysymys on tietenkin, vastaako hänen mallinsa taloustieteistä todellisuutta. Ovatko taloustieteilijät järkkymättömiä empiristejä jotka kyllä uskovat, kun evidenssi kääntää heidän päänsä? Rodrik myöntää, että monet julkisuudessa kaikkein näkyvimmistä taloustietelijöistä ovat pikemminkin toisen ääripään edustajia: niitä, joille taloustieteen rikkaus ei suinkaan tule mallien moninaisuudesta, vaan pikemminkin nimenomaan yhden standardimallin mahdollisimman laajasta soveltamisesta. Usein vieläpä nimenomaan mallitasolla, ilman empirian häivääkään.

Niinpä julkisen keskustelun kannalta on tavallaan ihan sama, vaikka kaikki mallikukat kukkisivat tieteen sisäisissä keskusteluissa, tai kuinka taloustieteilijät kritisoisivat toistensa ajatuksia vaikka vielä tiukemmin sanankääntein keskenään kuin ei-taloustietelijöiden ajatuksia. Kuten monissa arvioissa on todettu, Rodrik on mallia rakentava taloustieteilijä loppuun asti, ja hänelle ongelma on 
aina yksittäisten taloustietelijöiden käyttäytymisessä eikä niinkään tieteenalan platonisessa ideassa.

Rodrikin ohjeet taloustietelijöiden kanssa riitelyyn liittyvät siis ennen kaikkea esitettyjen mallien kriittisten oletusten löytämiseen ja mallin valinnan kritiikkiin: miksi juuri tässä kohdassa oletetaan näin, miten olisi oltava, jotta malli näyttäisi toisin, kenen hyvinvointia suositeltu politiikkatoimi kasvattaa, millaisia muita malleja olisi olemassa. Tässäpä ohjeita seuraavaan Twitter-keskusteluun.

Oikeastaan lopulta on vain toivottava, että Rodrik on muodostanut hyvin todellisuutta kuvaavan mallin taloustietelijöistä, tai vaihtoehtoisesti, että mahdollisimman moni taloustieteilijä mahdollisimman nopeasti myös lukisi Rodrikin kirjan. 